\title{
Legislative Update: March 2001
}

\section{Allison Weber Shuren, NP, JD*, and Stacy Harbison, BS\#}

\section{MedPAC STUDY}

The Medicare Benefits Improvement and Protection Act of 2000, also referred to as “BIPA,” provided for a MedPAC study on access to outpatient pain management services, a provision sponsored by ASIPP. This study is required to review the barriers to coverage and payment for outpatient interventional pain medicine procedures under the Medicare program, specifically as it relates to hospital outpatient departments, ambulatory surgery centers and physicians’ offices.

To aid MedPAC in the design of this study, Laxmaiah Manchikanti, MD; President, Kenneth G. Varley, MD, VicePresident; Joseph Walling, MD, Legislative/Public Relations Committee; Bentley Akobundu Ogoke, MD Board of Director of ASIPP; and Bill Sarraille, JD, and his associate Anna Spencer, JD, Washington counsel to ASIPP met with MedPAC on February 26, to offer background information on pain management practice and their thoughts and insights on the structure of this review. MedPAC appeared receptive to the information presented. ASIPP will continue to work with the study staff in the months ahead. The final must be completed in one year.

\section{PATIENTS’ BILL OF RIGHTS}

Two managed care reform bills have been introduced in the U.S. Senate and one bill has been introduced in the House of Representatives (H.R. 2926). On January 22, Minority Leader Daschle (D-SD) introduced S. 6, which includes a number of sections addressing issues such as internal and external appeals procedures, the establishment of a grievance process, and access to emergency and specialty care. The second Senate bill (S. 283) is a bipartisan

From Arent Fox Klintner Plotkin \& Khan, PLLC, Washington, D.C. * Ms. Shuren is an attorney at Arent Fox and Counsel for American Society of Interventional Pain Physicians. " Ms.Harbison is a Government Relations Assistant. Address correspondence: Allison Weber Shuren, JD, 1050 Connecticut Avenue NW, Washington, D.C. 20036 measure introduced by Senator McCain (R-AZ) and Senator Kennedy (D-MA) on February 7th and has the support of 16 cosponsors. A third Senate bill, representing the will of Administration is expected to be introduced by Senators Frist (R-TN), Jeffords (R-VT), and Breaux (D-LA) mid-March. Early reports of this latter measure suggest that it may expand the right for enrollees in ERISA health plans to sue their health plans.

Below is a brief summary of the two Senate bills as described by the Sponsors:

\section{S. 6 - The Patients' Bill of Rights Act}

- Protection for all Americans with private insurance;

- Coverage of needed emergency care;

- Access to needed specialists;

- An independent appeals process that delivers timely decisions when HMOs deny coverage; and

- The right to hold your health plan accountable when its decisions to deny or delay care lead to injury or death.

\section{S. 238 - Bipartisan Patient Protection Act of 2001}

- Gives every American the right to choose their own doctor;

- Covers all Americans with employer-based health insurance;

- $\quad$ Ensures that all external reviews of medical decisions are conducted by independent and qualified physicians; and

- Holds a plan accountable when the plan makes a decision that harms or kills someone.

\section{PRIVACY REGULATIONS}

By all reports it is unlikely that Congress will pass a comprehensive medical privacy law during this legislative session. Instead, according to an advisor to the Senate Health, Education, Labor and Pensions Committee, Congress will focus on the privacy standard released by the Department of Health and Human Services in December 2000. The regulation aims to protect the privacy of individually iden- 
tifiable health information as required by the Health Insurance Portability and Accountability Act of 1996 (HIPAA) and sets forth standards for electronic transmission of identifiable health information including claims and requests for payment. The rule addresses: 1) limitations on the use and disclosure of certain information; 2) imparts the ability of individuals to protect their own information; 3) institutes penalties for violations; and 4) establishes administrative procedures. Provided the rule remains unchanged, most covered entities have two years from the date of publication of the rule to implement the new regulations. However, in response to considerable criticism from industries such as retail pharmacies as well as some health provider groups the rule has been reopened for an another 30-day comment period. The fate of the rule as currently drafted, therefore, is uncertain.

\section{PRESCRIPTION DRUG COVERAGE UNDER THE MEDICARE PROGRAM}

Although prescription drug coverage is strongly desired by both sides of the aisle and is positioned to be an early topic of the 107th Congress, it may be difficult to reach a compromise on this divisive policy issue. President Bush has presented his Medicare drug proposal to Congress, which offers coverage to low-income seniors. The plan would give $\$ 48$ billion to states over a four year period to implement the proposed programs. It would provide full coverage for those living at or below 135 percent of poverty and would subsidize costs for those between 135 and 175 percent. Also, it would cover annual drug costs over $\$ 6,000$.

But it appears that the President's proposal has not been received well on Capitol Hill. Senator Grassley, Chairman of the Finance Committee, has mentioned his plans to have a committee vote on incremental Medicare legislation by August. The committee is anticipated to ground its work upon prescription coverage legislation led by Senators Frist (R-TN) and Breaux (D-LA).

In addition, the Finance Committee is expected to hold a number of Medicare hearings throughout the year, with prescription drug coverage slated for May. Other Medicare issues likely to be addressed include restructuring of HCFA; fee-for-service changes; and Medicare+Choice improvements.

\section{ERGONOMICS RULE OVERTURNED}

Congress opted to utilize its authority under a new law that gives Congress the ability to overturn agency actions in order to prevent implementation of the Occupational Safety and Health Administrations's ergonomics rule. The legislation which is expected to be signed into law by the President was pushed for by a number of businesses and trade associations that alleged the rule was too onerous.

\section{NEEDLESTICK PREVENTION AND SAFETY ACT REGULATIONS PART OF 60-DAY REVIEW}

The Needlestick Prevention and Safety Act signed into law in November 2000 requires covered employers, among other things, to maintain a log describing all "sharps” injuries, even those without sero-conversion. Existing OSHA recordkeeping requirements already require employers to capture similar incidence data, however, creating duplicative mandates. OSHA recognized and addressed the overlap in promulgating the regulations implementing the Needlestick Act, but because the revision is not slated to go into effect until January 2002 employers are faced with double recordkeeping requirements in the interim. Although some in the industry expect that OSHA will not enforce the sharps log requirement over the next year due to the duplication of the regulations, the Administration is reviewing the rule as part of its 60-day moratorium on all new regulations issued during the final days of the Clinton administration.

\section{SUBJECTS OF CLINICAL TRIAL SUE IRB MEMBERS}

In a case believed to be one of first impression, subjects of a cancer clinical trial that was suspended last year by the Office for Human Research Protections (OHRP) for allegedly inadequate human subjects protections filed suit against the University of Oklahoma Health Sciences Center IRB and each of its members in their individual capacity. Specifically, the plaintiffs' allege that their constitutional right to be treated with dignity was violated. The plaintiff's base their allegation on OHRP audit findings that the IRB failed to conduct meaningful continuing review of the study and allowed the informed consent documents to understate the risks of the trial and overstate the potential benefits of participation. While many believe that the charges against the individual members eventually will be dropped, the case has, nevertheless, sent a chill through the research community as it awaits information as to whether the complaint will survive legal challenge. 


\section{HCFA REFORM LIKELY}

Shortly after taking office as the Secretary of the Department of Health and Human Services, Tommy Thompson received a letter from Representative Billy Tauzin, Chairman of the House Commerce Committee, and Representatives Biliarakis and Greenwood outlining the Commerce Committee's intent to begin a broad review of HCFA's policies, regulations and operations. The Committee's goal, according to the letter, is to eliminate [what it views as] undue bureaucracy and to modernize HCFA's infrastructure. As part of the initiative, coined "Patients First: A 21st Century Promise to Ensure Quality and Affordable Health Coverage," the Commerce Committee expects to hold as many as ten hearings in order to examine every aspect of HCFA's operations. The first hearing was held March 1st. In addition to his overtures to Thompson, Chairman Tauzin also has sought input from the AMA. The House Ways and Means and Senate Finance Committees also are expected to hold hearings on HCFA reform throughout the Spring.

In addition to the intended Congressional reform efforts, the Bush Administration has vowed to work with Thompson and the new HCFA administrator to revamp the agency to increase its effectiveness. Possible changes under consideration include a proposal to move Medicaid out of HCFA.

\section{COMMITTEE MAKE-UP IN THE $107^{\text {th }}$ CONGRESS}

The chairmen of the health related committees of interest to ASIPP are as follows:

\section{SENATE:}

- Committee on Finance - jurisdiction over the Medicare program

- $\quad$ Senator Grassley (R-IA), Chairman

- $\quad$ Senator Baucus (D-MT), Ranking Minority Member

- $\quad$ Subcommittee on Health Care

- $\quad$ Senator Craig (R-ID), Chairman

- $\quad$ Senator Rockefeller (D-WV), Ranking Minority Member

- Committee on Health, Education, Labor and Pensions - jurisdiction over general health related legislation

- $\quad$ Senator Jeffords (R-VT), Chairman

- $\quad$ Senator Kennedy (D-MA), Ranking
Minority Member

- $\quad$ Subcommittee on Public Health

- $\quad$ Senator Frist (R-TN), Chair-

man

- $\quad$ Senator Kennedy (D-MA), Ranking Minority Member

- $\quad$ Committee on Appropriations

- $\quad$ Senator Stevens (R-AK), Chairman

- $\quad$ Senator Byrd (D-WV), Ranking Minority Member

- $\quad$ Subcommittee on Labor, Health and Human Services, and Education

- $\quad$ Senator Specter (R-PA), Chairman

- $\quad$ Senator Harkin (D-IA), Ranking Minority Member

HOUSE:

- $\quad$ Committee on Energy and Commerce - jurisdiction over the Medicare program

- $\quad$ Congressman Tauzin (R-LA), Chairman

- $\quad$ Congressman Dingell (D-MI), Ranking Minority Member

- $\quad$ Subcommittee on Health and Environment

- $\quad$ Congressman Bilirakis (R-FL), Chairman

- $\quad$ Congressman Brown (D-OH), Ranking Minority Member

- Committee on Ways and Means - jurisdiction over the Medicare program

- $\quad$ Congressman Thomas (R-CA), Chairman

- $\quad$ Congressman Rangel (D-NY), Ranking Minority Member

- $\quad$ Subcommittee on Health

- $\quad$ Congresswoman Johnson (RCT), Chair

- $\quad$ Congressman Stark (D-CA), Ranking Minority Member

- Committee on Appropriations

- $\quad$ Congressman Young (R-FL), Chairman

- $\quad$ Congressman Obey (D-WI), Rankirng Minority Member

- $\quad$ Subcommittee on Labor, Health and Human Services, Education and Related Agencies

- $\quad$ Congressman Young (R-FL)

- $\quad$ Congressman Obey (D-WI)

$* * *$ 